\author{
M. Ye. Blazheyevskiy, O. V. Koval'ska, K. V. Dynnyk
}

National University of Pharmacy of the Ministry of Health of Ukraine, Ukraine

53, Pushkinska str., Kharkiv, 61002. E-mail: lena05021985@ukr.net

\title{
A novel luminol-based chemiluminescence method for detecting acetylcholine
}

Aim. To develop a new simple non-enzymatic method for the determination of acetylcholine (ACh) by the chemiluminescent reaction of luminol under conditions of the enzymatic hydrolysis of acetylcholine ( $\mathrm{pH}$ 8.5).

Experimental part. The method proposed is based on the perhydrolysis reaction of ACh by the excess of hydrogen peroxide with the formation of peracetic acid. The latter was further determined by the activation effect of the luminol chemiluminescent oxidation reaction in the presence of hydrogen peroxide. The analytical signal was the summary luminescence $(\Sigma)$ registered within certain time.

Results and discussion. The $\mathrm{pH}$ range of the analytically applicable system was from 8.2 to 8.5 . The effect of $\mathrm{ACh}+\mathrm{H}_{2} \mathrm{O}_{2}$ incubation period on the reaction progress was also studied. The increase of the incubation period enhanced the sensitivity of the method (the limit of detection (LOD)), but because of practical reasons (especially the detection speed) and practical experience the incubation period was set to $30 \mathrm{~min}$. The linear dependence was observed in the acetylcholine chloride concentration range of $(0.8-2.8) \times 10^{-4} \mathrm{~mol} / \mathrm{L}$. While determining acetylcholine chloride in the concentration range of $(1.1-2.2) \times 10^{-4} \mathrm{~mol} / \mathrm{L}$ the relative standard deviation (RSD) did not exceed $3 \%((\bar{X}-\mu) \times 100 \% / \mu=-0.5 \ldots+0.5 \%)$. The Limit of Quantitation (LOQ, 10S) was $7.7 \times 10^{-5} \mathrm{~mol} / \mathrm{L}$.

Conclusions. A new non-enzymatic kinetic method for the chemiluminescent determination of ACh in aqueous solutions and the pharmaceutical formulation Acetylcholinchlorid Injeel ${ }^{\circledR}$ has been proposed. This method is simple, fast, inexpensive, and thus appropriate for the routine ACh quality control in the laboratories of hospitals, pharmaceutical industries and research institutions.

Key words: acetylcholine; chemiluminescence method

\section{М. Є. Блажеєвський, О. В. Ковальська, К. В. Динник}

Національний фрармацевтичний університет Міністерства охорони здоров'я України, Україна

Новий хемілюмінесцентний метод визначення ацетилхоліну 3 використанням люмінолу

Мета. Розробити новий простий неферментативний метод визначення ацетилхоліну (ACh) за допомогою хемілюмінесцентної реакції люмінолу за умов ферментативного гідролізу ацетилхоліну $(\mathrm{pH} 8,5)$.

Експериментальна частина. Запропонований спосіб засновано на реакції пергідролізу ацетилхоліну надлишком пероксиду водню з утворенням пероцтової кислоти. Пероцтову кислоту далі визначали за допомогою ефекту активації реакції хемілюмінесцентного окиснення люмінолу в присутності пероксиду водню. Аналітичним сигналом була сумарна люмінесценція $(\Sigma)$ за певний час.

Результати та їх обговорення. Діапазон рН аналітично застосовної системи становив від 8,2 до 8,5. Додатково досліджено вплив інкубаційного періоду $\mathrm{ACh}+\mathrm{H}_{2} \mathrm{O}_{2}$ на перебіг реакції. Збільшення інкубаційного періоду підвищило чутливість методу (межу виявлення (LOD)), але з практичних причин (особливо швидкості визначення) та практичного досвіду інкубаційний період було зафріксовано на рівні 30 хв. Лінійна залежність спостерігалась у діапазоні концентрацій ацетилхолін хлориду $(0,8-2,8) \times 10^{-4}$ моль/л. За визначення ацетилхолін хлориду в модельному розчині в межах концентрацій $(1,1-2,2) \times 10^{-4}$ моль/л відносне стандартне відхилення RSD не перевищувало $3 \%((\bar{X}-\mu) \times 100 \% / \mu=-0,5 \ldots+0,5 \%)$. Межа кількісного визначення (LOQ, 10S) становила 7,7 × 10-5 моль/л.

Висновки. Запропоновано новий неферментативний кінетичний метод для хемілюмінесцентного визначення ацетилхоліну у водних розчинах та фармацевтичному засобі Acetylcholinchlorid Injeel ${ }^{\circledR}$. Цей метод є простим, швидким, недорогим і придатним для рутинного контролю якості ацетилхоліну в лабораторіях лікарень, фрармацевтичної промисловості та науково-дослідних установ.

Ключові слова: ацетилхолін; хемілюмінесцентний метод

Copyright $\odot$ 2021, M. Ye. Blazheyevskiy, O. V. Koval'ska, K. V. Dynnyk This is an open access article under the CC BY license (http://creativecommons.org/licenses/by/4.0)

Acetylcholine (ACh) (Fig. 1) is a neurohormone of the autonomic nervous system playing an important role in maintaining the vital functions of a living organism.

ACh was the first neurotransmitter to be characterized. It is the primary neurotransmitter in muscular synapses. In the central nervous system (CNS) it is associated with attention, learning, memory, consciousness, sleeping, and control of voluntary move- ments [1]. Disruption of normal ACh signaling is implicated in Huntington's disease, Alzheimer's disease, schizophrenia, and Parkinson's disease [2], endarteritis, intermittent claudication, spasms of retinal arteries, intestinal and bladder atony. It is used to facilitate radiographic diagnosis of esophagus achalasia [3].

When the nerve impulse reaches the end of an axon, ACh is released transmitting the impulse further. This action of ACh is subsequently 
<smiles>CC(=O)OCC[N+](C)(C)C</smiles>

Fig. 1. Acetylcholine chloride

discontinued as a result of its hydrolysis catalyzed by the cholinesterase enzyme presented in living tissues (Scheme 1).

In order to study various disorders mentioned above and develop new medicines, it is important to measure the ACh concentration with simple, fast, inexpensive, and accurate methods.

For the quantitative determination of acetylcholine chloride the European Pharmacopoeia and US Pharmacopoeia use the method of acidimetry $[4,5]$. According to the current analytical normative documentation, the content of the main substance is argentometrically determined by Folgard or LC [4]. The titrimetric procedures are highly accurate, but are not specific to ACh. A colorimetric method widely used in the practice of biological researches for determining ACh concentration was proposed by Hestrin [6].

Common procedures for $\mathrm{ACh}$ detection include the high-performance liquid chromatography (HPLC) method on microdialysis samples [7], electrochemical methods using potentiometric and amperometric sensors [8] and ion-sensitive field-effect transistors (ISFETs) [9].

HPLC on microdialysis samples has very high resolution in the pM range. However, this method has disadvantages, namely the tedious sample pretreatment and high cost (a microdialysis probe costs about $\$ 200$ ).

A simple, rapid and sensitive optical biosensor for detection of choline and ACh based on the hydrogen peroxide $\left(\mathrm{H}_{2} \mathrm{O}_{2}\right)$-sensitive quantum dots (QDs) was constructed. The detection limit for ACh was found to be $10 \mu \mathrm{M}$, and the linear range was $10-5000 \mu \mathrm{M}$. The wide linear ranges were shown to be suitable for routine analyses of choline and ACh. The detection linear range of ACh in the serum was 10-140 $\mu \mathrm{M}$. The excellent performance of this biosensor showed that the method can be used in practice detection of choline and ACh. The performance of the device exceeds most reported ACh microsensors. However, the characteristic curve is not linear, and calibration is required for this device [10].

Ternaux and Chamoin described an enhanced chemiluminescence assay method for the determination of ACh [11]. In some methods ACh was hydrolyzed by acetylcholinesterase before the analysis [12]. Electron transfer and oxidation by hydrogen peroxide were facilitated by immobilizing the enzyme on a redox polymer [13].

ACh is not electroactive, thus, it cannot be analyzed by electrochemical methods. Therefore, methods recently published for monitoring ACh involve either biosensor or MS detection. Biosensors were used for the direct detection of ACh or preceded by LC. A common biosensor scheme requires co-immobilization of acetylcholinesterase and choline oxidase. ACh is converted to choline, and choline is further oxidized by choline oxidase to produce hydrogen peroxide, which is detected. Since choline is a normal metabolite of ACh in vivo, another biosensor coated only with choline oxidase is often used together with the ACh biosensor to measure and subtract out the signal due to endogenously occurring choline. As with all biosensors or microelectrodes, major concerns are their selectivity and sensitivity in relation to a target molecule. Therefore, interfering electroactive species were excluded from ACh electrodes with permiselective membranes composed of over oxidized poly(pyrrole)-poly(2-naphthol) films [14]. Carballo et all demonstrated liquid chromatography with the electrochemical detection (LC-EC) system using an electrode for the detection of ACh $[15,16]$.

Those methods published for the determination of ACh by LC-MS in dialysate or cell culture samples sought rapid separations and a sensitive detection with the minimal ion suppression during ESI [17-19].

In some new enzymatic methods based on the use of two sequential reactions involving acetylcholinesterase and choline oxidase, the control of the content of hydrogen peroxide is carried out by the chemiluminescent method following the catalytic oxidation reaction of the chemiluminescent luminol indicator in the presence of the enzyme peroxidase $[10,12]$.

In this article a new kinetic-chemiluminescent method for the determination of acetylcholine chloride has been proposed. It is based on the application of a conjugated system of two successive reactions ACh perhydrolysis and oxidation reaction of the chemiluminescence indicator luminol $\left(\mathrm{H}_{2} \mathrm{~L}\right)$ induced by peracetic acid formed at the first stage.

Peracetic acid formed as the result of ACh perhydrolysis reacts with luminol in the presence of hydrogen peroxide with the generation of chemiluminescence measured by the chemiluminescence method of the fixed time. The scheme of luminol oxidation is given in Scheme 2.

Based on the experimental data it was found that within the $\mathrm{pH}$ range of 8.2-8.5 the intensity of chemi-

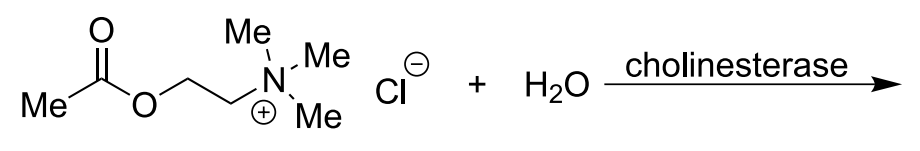

acetylcholine chloride<smiles>CC(=O)[OH+]CC[N+](C)(C)[O-]</smiles>

acetic acid choline chloride 


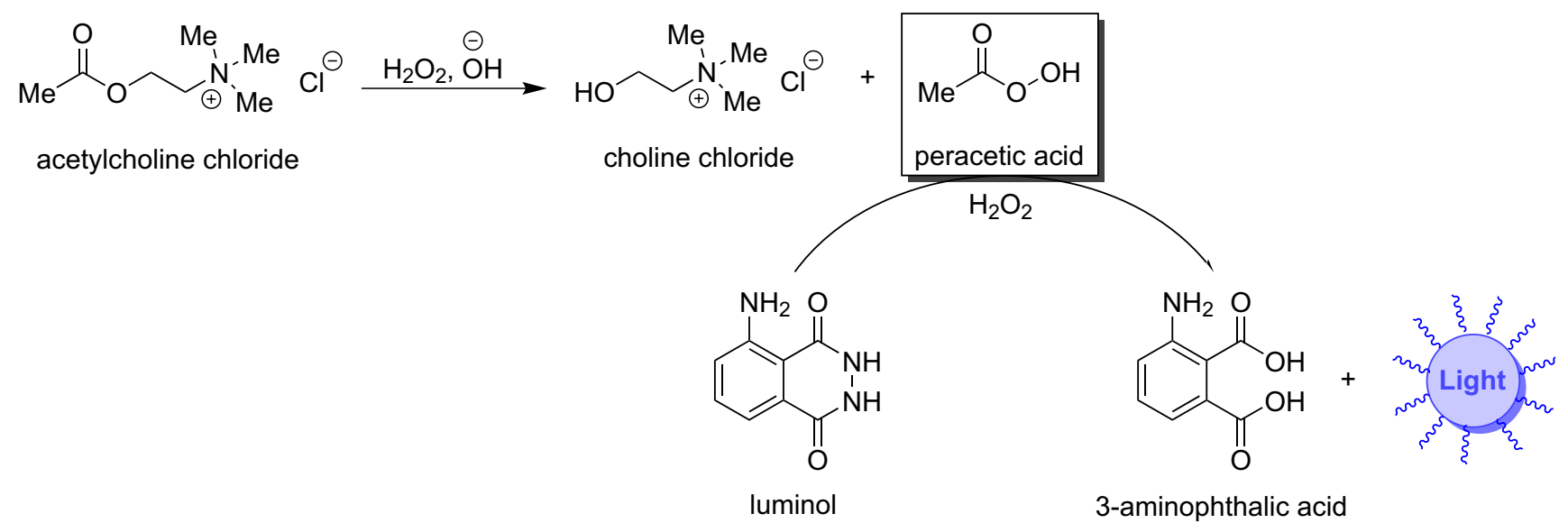

Scheme 2. The reaction scheme of ACh perhydrolysis and chemiluminescent oxidation of luminol

luminescence (emitted by oxidation of luminol with peracetic acid in the presence of hydrogen peroxide) was directly proportional to the concentration of ACh. The initial stage - ACh perhydrolysis - determined the rate of the whole process. The kinetic curves of chemiluminescence produced in the reaction of luminol with hydrogen peroxide in the presence of $\mathrm{ACh}$ are shown in Fig. 2.

\section{Experimental Part}

Acetylcholine chloride - 99\% (Acros), argentometric titration $-\geq 98.5 \%$ (on dried base); the loss on drying $-\leq 1.0 \%\left(105^{\circ} \mathrm{C}, 3 \mathrm{~h}\right)$; the molecular formula $\mathrm{C}_{7} \mathrm{H}_{16} \mathrm{ClNO}_{2}$; the molecular weight $-181.66 \mathrm{~g} / \mathrm{mol}$.

Luminol (5-amino-2,3-dihydro-1,4-phthalazinedione, $\mathrm{H}_{2} \mathrm{~L}$, Sigma-Aldrich, 97\%) was additionally recrystallized from a saturated solution of sodium hydroxide. All other chemicals were of analytical grade. Solutions were prepared with double distilled water produced in a quartz water distiller.

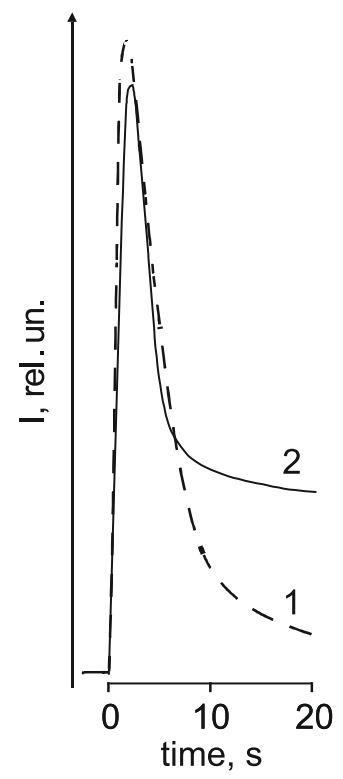

Fig. 2. The effect of ACh (ACh-luminol- $\mathrm{H}_{2} \mathrm{O}_{2}$, 2) on the intensity of chemiluminescence in the luminol- $\mathrm{H}_{2} \mathrm{O}_{2}(1)$ system for the reaction time of $20 \mathrm{sec}, w(\mathrm{ACh}): \mathbf{1}-0 \% ; 2-1.5 \cdot 10^{-3} \%$; $c\left(\mathrm{H}_{2} \mathrm{~L}\right)=5.0 \cdot 10^{-5} \mathrm{~mol} / \mathrm{L} ; w\left(\mathrm{H}_{2} \mathrm{O}_{2}\right)=5.0 \cdot 10^{-2} \% ; \mathrm{pH} 8.5$
Acetylcholinchlorid Injee $\mathrm{l}^{\circledR}$ (Biologische Heilmittel Heel GmbH) - composition: 1 ampoule of $1.1 \mathrm{~mL}$ contains as an active ingredient acetylcholine chloratum $0.367 \mathrm{~g}$ (on dried base), ethanol 43\% (w/w). Excipient: sodium chloride.

The stock solution of acetylcholine chloride $\left(2.75 \cdot 10^{-2} \mathrm{~mol} / \mathrm{L}\right)$ was prepared daily and stored at $4^{\circ} \mathrm{C}$. The analyte was weighed using a calibrated scale (model AG204, Mettler-Toledo, Greifensee, Switzerland).

The experiment conditions used in the research were selected based on the literature sources [21-23].

Preparation of the Working Standard Solution of acetylcholine chloride, $5.07 \mathrm{mg} / \mathrm{mL}$. Dissolve $0.50717 \mathrm{~g}$ of acetylcholine chloride reference standard ex tempore in degassed double distilled water to make $100.00 \mathrm{~mL}$ of solution. Store in a high-density polyethylene or polypropylene bottle at $4^{\circ} \mathrm{C}$.

The content of ACh in the solution was controlled by argentometric titration [6]. Working solutions with a smaller amount of acetylcholine chloride were prepared daily by diluting accurately the stock solution.

Preparation of phosphate buffer, pH 8.5

To $250.0 \mathrm{ml}$ of $0.2 \mathrm{~mol} / \mathrm{L}$ solution of disodium phosphate add $8.0 \mathrm{~mL}$ of $0.1 \mathrm{~mol} / \mathrm{L}$ of hydrogen chloride solution. The $\mathrm{pH}$ control was carried out potentiometrically using a glass electrode ELS-43-07 and I-130 ionomer.

Preparation of hydrogen peroxide solution, 5\% (1.5 mol/L). Dissolve $16.5 \mathrm{~g}$ of $30 \%$ hydrogen peroxide in water in a $100 \mathrm{~mL}$ volumetric flask and dilute the solution to the volume with water. The content of hydrogen peroxide in the solution was controlled by the method of permanganometry.

Preparation of $0.01 \mathrm{~mol} / \mathrm{L}$ stock solution of luminol in $0.01 \mathrm{~mol} / \mathrm{L}$ solution of sodium hydroxide. Dissolve $0.1772 \mathrm{~g}$ of luminol in $100.0 \mathrm{~mL}$ of $0.01 \mathrm{~mol} / \mathrm{L}$ solution of sodium hydroxide. Dilute the resulting solution of luminol 10 times with double distilled water.

The chemiluminescence intensity was measured using an assembled chemiluminescence installation (Chemiluminometer-01), including a FEU-84-A 


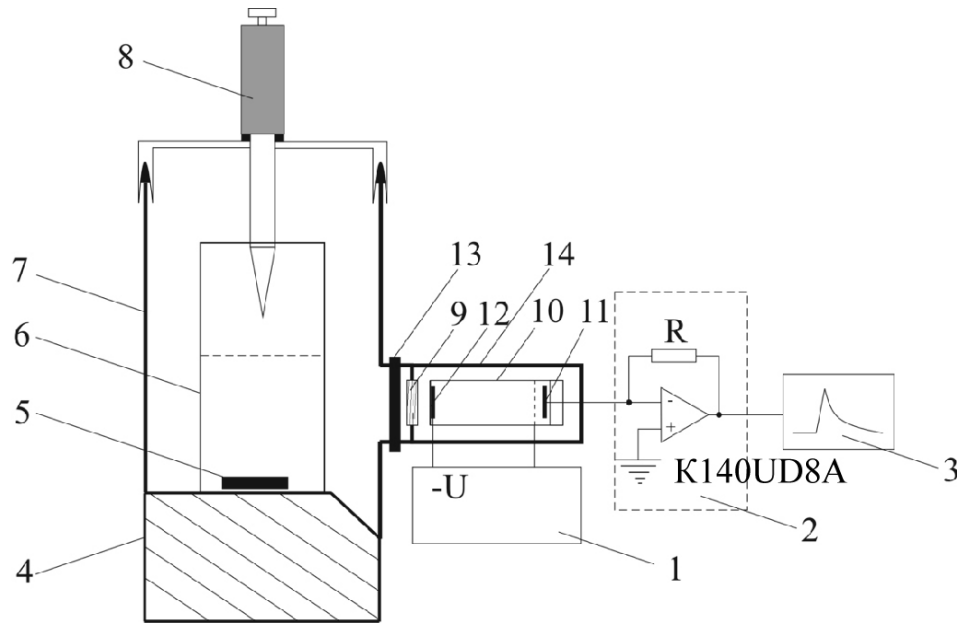

1 - PEM power supply source (high -voltage stabilizer);

2 - current -voltage converter;

3 - recording potentiometer;

4 - magnetic mixer;

5 - impeller in Teflon;

6 - crystal measuring cell;

7 - opaque chamber;

8 - adjustable pipettor $(P-1)$ with an opaque seal;

9 - light filter;

10 - photoelectric multiplier (PEM) FEU-84A;

11 - PEM anode;

12 - PEM cathode;

13 - blind;

14 - aluminium screen.

Fig. 3. The installation for measuring chemiluminescence

photoelectric-multiplier (PEM), a IMT-0.5 weak current meter and a LINE RECORDER TZ 4620 fast-operating recording potentiometer (Laboratorni pristroje, Czech Republic) (Fig. 3).

The procedure for the quantitative determination of acetylcholine by the chemiluminescence method. When studying the impact of the ACh concentration on chemiluminescence in the $\mathrm{ACh}+$ buffer $+\mathrm{H}_{2} \mathrm{O}_{2}$ ) $+\mathrm{H}_{2} \mathrm{~L}$ system, an order of operations was as follows. A sample of the test solution of ACh (from 0.10 to $1.00 \mathrm{~mL}$ ), $1.00 \mathrm{~mL}$ of $5 \%$ solution of hydrogen peroxide and $(10-Y) \mathrm{mL}$ of $0.2 \mathrm{~mol} / \mathrm{L}$ of the phosphate buffer solution ( $\mathrm{pH}$ 8.5) (where «Y» is the total volume of all other components in the solution) were added into a flask with a lapped stopper, and all components were mixed thoroughly. The flask was left in the thermostat at $40^{\circ} \mathrm{C}$ for $15 \mathrm{~min}$. Then $1.00 \mathrm{~mL}$ of the resulting mixture was taken and placed in a quartz cuvette, with stirring, $8.5 \mathrm{~mL}$ of phosphate buffer solution ( $\mathrm{pH}$ 8.5) was added, and the cuvette was placed in a measuring cell of a chemiluminescent photometer. After that the curtain was opened and $0.5 \mathrm{~mL}$ of $1 \times 10^{-3} \mathrm{~mol} / \mathrm{L}$ of luminol solution was added to the cuvette. The total luminescence was recorded using an I-02 digital automatic integrator for $20 \mathrm{sec}$. The dependence of the chemiluminescence intensity on time (sec) was registered on the kinetic graph (Fig. 2). The experiment was repeated five times. The desired signal was the area under the curve the integral of the chemiluminescence over time period $(20 \mathrm{sec})(\Sigma$, relative units (rel. un.)) obtained by averaging the values of five experiments. The sensitivity was $2 \mathrm{mV}$, and the chart speed was $\mathrm{v}=0.6 \mathrm{~cm} / \mathrm{min}$. All experiments were conducted at 18 to $20^{\circ} \mathrm{C}$. The content of acetylcholine was found on the calibration graph.

The control experiment was performed as follows: $9.0 \mathrm{~mL}$ of $0.2 \mathrm{~mol} / \mathrm{L}$ phosphate buffer solution ( $\mathrm{pH} 8.5$ ) 28 and $1.0 \mathrm{~mL}$ of $5 \%$ solution of hydrogen peroxide were added to a $10 \mathrm{~mL}$ tube with a lapped stopper with stirring. $1.00 \mathrm{~mL}$ of the solution was introduced into the cuvette, stirred with $8.5 \mathrm{~mL}$ of phosphate buffer (pH 8.5), and the cell was placed in a chemiluminescent photometer. The curtain was opened, and the value of integral chemiluminescence was registered using an I-02 digital automatic integrator for $20 \sec (\Sigma$, rel. un.).

The method of obtaining the data for the calibration curve. In a tube with a lapped stopper, $(10-Y) \mathrm{mL}$ of $0.2 \mathrm{~mol} / \mathrm{L}$ phosphate buffer solution (pH 8.5) (where " $Y$ " is the total volume of all other components in the solution), $1.00 \mathrm{~mL}$ of $5 \%$ solution of hydrogen peroxide and a sample of the test solution of ACh $(0.10 ; 0.20 ; 0.40 ; 0.50 ; 0.70$ and $1.00 \mathrm{~mL}$ ) were added. The analysis was performed in the same way as when testing model solutions (see the procedure above).

\section{Results and discussion}

A series of experiments allowed us to determine the dependence of integral chemiluminescence $(\Delta \Sigma$, rel. un.) on the concentration of ACh in the cell (c, mol/L) (Fig. 4). The linear dependence was observed on the acetylcholine chloride concentration range of $(0.8-2.8) \times 10^{-4} \mathrm{~mol} / \mathrm{L}$ (Table 1 ).

The concentration of ACh was calculated using the following formula:

$$
c=\frac{(\Delta \Sigma-a) \times 10 \times 10}{b \times V_{a} \times 1},
$$

where: $a$ - is the axis intersection of the calibration curve equation ( $\operatorname{tg} \alpha=\mathrm{bc}+\mathrm{a}$ ), rel. un.; $b$ - is the slope of the calibration curve equation ( $\operatorname{tg} \alpha=b c+a)$ - the coefficient of instrumental sensitivity, $\mathrm{L} / \mathrm{mol} ; \Delta \Sigma$ - is the difference in values of integral chemiluminescence 
Table 1

\section{Regression output}

\begin{tabular}{|c|c|}
\hline Parameter & Data \\
\hline $\begin{array}{c}\text { Regression equation } \\
\mathrm{y}=a+b \mathrm{c}\end{array}$ & $\mathrm{y}=(250.4 \pm 31.2) \times 10^{3} \mathrm{c}$ \\
\hline $\begin{array}{c}\text { Correlation coefficient }(\mathrm{r}) \\
\mathrm{S}_{\mathrm{a}}\end{array}$ & 0.998 \\
\hline $\mathrm{S}_{\mathrm{b}}$ & 1.931073 \\
\hline $\mathrm{a}$ & 11273.28 \\
\hline $\mathrm{b}$ & -0.9694 \\
\hline$\Delta a=\mathrm{S}_{a} \times t_{\mathrm{a}}$ & 250448 \\
\hline$\Delta b=\mathrm{S}_{b} \times t_{a}$ & 5.36152 \\
\hline$L O D=3 \mathrm{~S}_{d} / b$ & 31230 \\
\hline$L O Q=3.3 \times L O D$ & $2.3 \times 10^{-5} \mathrm{~mol} / \mathrm{L}$ \\
\hline
\end{tabular}

in the working and control (without ACh) experiments, in relative light units; $V_{a}$ - is the volume of the sample solution taken for testing, $\mathrm{mL} ; 10,10$ - is the dilution.

The results of determining acetylcholine chloride in model solutions by the chemiluminescence method using the reaction with hydrogen peroxide and luminol is presented in Table 2 .

The procedure of the ACh assay in Acetylcholinchlorid Injeel ${ }^{\circledR}$ (Biologische Heilmittel Heel GmbH). The procedure was as follows: $1.00 \mathrm{~mL}$ solution contained in an ampoule of Acetylcholinchlorid Injeel ${ }^{\circledR}$ (Biologische Heilmittel Heel GmbH) $(0.367$ g (on dried base) in $1.1 \mathrm{~mL}$ ) was quantitatively transferred into a $100 \mathrm{~mL}$ volumetric flask, and double distillated water was added to make $100 \mathrm{~mL}$ solution. The micropipettes were used to introduce a sample of the test solution of ACh prepared $(1.00 \mathrm{~mL}), 1.00 \mathrm{~mL}$ of $5 \%$ solution of hydrogen peroxide and $(10-Y) \mathrm{mL}$ of $0.2 \mathrm{~mol} / \mathrm{L}$ phosphate buffer solution (pH 8.5) (where " $Y$ " is the total volume of all other components of the solution) into a tube with a lapped stopper, and the content was mixed thoroughly. The analysis was performed in the same way

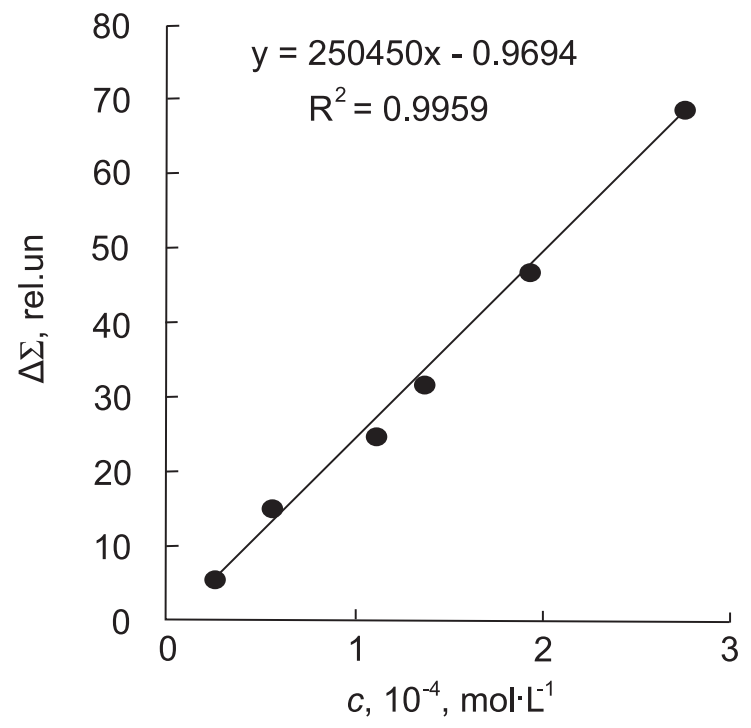

Fig. 4. The dependence of integral chemiluminescence $(\Delta \Sigma$, rel. un.) on the concentration of $\mathrm{ACh}$ in the cell $(c, \mathrm{~mol} / \mathrm{L})$

as when testing model solutions (see the procedure above "The procedure for the quantitative determination of acetylcholine by the chemiluminescence method").

Accurately weighed $0.367 \mathrm{~g}$ of acetylcholine chloride reference standard was dissolved ex tempore in degassed double distilled water to make $100.00 \mathrm{~mL}$ of solution. The micropipettes were used to introduce a sample of standard solution of acetylcholine $(1.00 \mathrm{~mL})$, $1.00 \mathrm{~mL}$ of $5 \%$ solution of hydrogen peroxide and $(10-Y) \mathrm{mL}$ of $0.2 \mathrm{~mol} / \mathrm{L}$ phosphate buffer solution (pH 8.5) (where «Y» is the total volume of all other components of the solution) into a tube with a lapped stopper, and all the components were mixed thoroughly. The flask was left in the thermostat at $40^{\circ} \mathrm{C}$ for $15 \mathrm{~min} .1 .00 \mathrm{~mL}$ of the resulting mixture was collected and placed in a quartz cuvette, with stirring, $8.5 \mathrm{~mL}$ of phosphate buffer solution $(\mathrm{pH} 8.5)$ was added, and the cuvette was placed in a measuring cell of a chemiluminescent photometer. After the curtain opening $0.5 \mathrm{~mL}$ of $1 \times 10^{-3} \mathrm{~mol} / \mathrm{L}$ of luminol solution was added. The total luminescence was registered using an I-02 digital automatic integrator for $20 \mathrm{sec}$. The expe-

Table 2

The results of the acetylcholine chloride determination in model solutions by the chemiluminescence method using the reaction with hydrogen peroxide and luminol $(P=0.95, n=5)$

\begin{tabular}{|c|c|c|c|c|}
\hline C taken, $10^{-4} \mathrm{~mol} / \mathrm{L}$ & C found, $10^{-4} \mathrm{~mol} / \mathrm{L}$ & Recovered, $\mathrm{mol} / \mathrm{L}$ & $\mathrm{RSD}, \%$ & $\delta, \%$ \\
\hline 1.10 & $1.10 ; 1.06 ; 1.13 ; 1.07 ; 1.13$ & $(1.10 \pm 0.04) \times 10^{-4}$ & 3.0 & $0 \%$ \\
\hline 1.38 & $1.43 ; 1.41 ; 1.36 ; 1.35 ; 1.37$ & $(1.38 \pm 0.04) \times 10^{-4}$ & 2.5 & $0 \%$ \\
\hline 1.93 & $1.97 ; 1.93 ; 1.94 ; 1.89 ; 1.86$ & $(1.92 \pm 0.05) \times 10^{-4}$ & 2.3 & $-0.5 \%$ \\
\hline 2.20 & $2.15 ; 2.21 ; 2.26 ; 2.20 ; 2.25$ & $(2.21 \pm 0.055) \times 10^{-4}$ & 2.0 & $+0.45 \%$ \\
\hline
\end{tabular}


riment was repeated five times.

The control experiment was performed as it was mentioned above (see "Procedure for the quantitative determination of acetylcholine by the chemiluminescence method").

The content of ACh (X (g) of a dried substance) in one ampoule was calculated by the following formula:

$$
\mathrm{X}=\left(\Delta \Sigma x \times m_{s t} \times w_{s t} \times V\right) /(\Delta \Sigma s t \times 100 \times 1.00),
$$

where: $m_{\text {st }}$ - is the standard sample weight, $\mathrm{g} ; w_{s t}$ - is the content of anhydrous ACh, \%; 1.00 - is the volume of the test solution taken for analysis, $\mathrm{mL} ; V$ - is the average volume of the solution in ampoules, $\mathrm{mL} ; \Delta \Sigma X-$ is the difference in values of integral chemiluminescence in the working and control (without ACh) experiments in relative light units; $\Delta \Sigma s t$ - is the difference in values of integral chemiluminescence in the standard solution and control (without ACh) experiment in relative light units.

The results of the ACh analysis in the pharmaceutical formulation Acetylcholinchlorid Injeel ${ }^{\circledR}$ (Biologische Heilmittel Heel $\mathrm{GmbH}$ ) by the method proposed $(n=7, P=0.95)$ are presented in Table 3 .

From the results given above, we can conclude that this chemiluminescent method is a fast, simple and non-enzymatic approach for the quantitative determination of ACh in aqueous solutions; it is based on the reaction of perhydrolysis of ACh to peracetic acid and the subsequent chemiluminescent de-
Table 3

The results of $\mathrm{ACh}$ the analysis in the pharmaceutical formulation Acetylcholinchlorid Injeel ${ }^{\circ}$

(Biologische Heilmittel Heel $\mathrm{GmbH}$ )

by the method proposed $(n=7, P=0.95)$

\begin{tabular}{|c|c|c|}
\hline Labelled amount, g/amp & Recovered \pm RSD, \% & $\delta, \% *$ \\
\hline 0.367 & $99.5 \pm 1.9 \%$ & $-0.5 \%$ \\
\hline
\end{tabular}

Note: $* \delta=(\bar{X}-\mu) \times 100 \% / \mu$

termination of its amount by the reaction of chemiluminescent oxidation of luminol. While determining acetylcholine chloride in the concentration range of $(1.1-2.2) \times 10^{-4} \mathrm{~mol} / \mathrm{L}$ the relative standard deviation did not exceed 3\% (RSD $\leq 3 \%,((\bar{X}-\mu) \times 100 \% /$ $\mu=-0.5 \ldots+0.5 \%)$ ). The limit of quantitation (LOQ $10 \mathrm{~S}$ ) was $7.7 \times 10^{-5} \mathrm{~mol} / \mathrm{L}$.

\section{Conclusions}

A new non-enzymatic kinetic method for the chemiluminescent determination of acetylcholine in aqueous solutions and the pharmaceutical formulation Acetylcholinchlorid Injeel ${ }^{\circledR}$ has been proposed. This method is simple, fast, inexpensive, and thus appropriate for the routine acetylcholine quality control in the laboratories of hospitals, pharmaceutical industries and research institutions.

Conflict of interests: the authors have no conflict of interests to declare.

\section{References}

1. Picciotto, M. R.; Higley, M. J.; Mineur, Yann S. Acetylcholine as a Neuromodulator: Cholinergic Signaling Shapes Nervous System Function and Behavior. Neuron 2012, 76 (1), 116-129. https://doi.org/10.1016/j.neuron.2012.08.036.

2. Berridge, M. J. Dysregulation of neural calcium signaling in Alzheimer disease, bipolar disorder and schizophrenia. Prion 2013, 7 (1), 2-13. https://doi.org/10.4161/pri.21767.

3. VIDAL. Справочник лекарственных средств. Acetylcholine chloride. https://www.vidal.ru/drugs/molecule/1181 (accessed Dec 17, 2020 ).

4. European Pharmacopoeia, $9^{\text {th }}$ Ed.; European Department for the Quality of Medicines: Strasbourg, 2016.

5. The United States pharmacopeia USP35, the national formulary NF30; United States Pharmacopeial Convention, Inc.: Rockville, MD, 2012.

6. Hestrin, S. The reaction of acetylcholine and other carboxylic acid derivatives with hydroxylamine, and its analytical application. J. Biol. Chem. 1949, 180 (1), 249-261. https://doi.org/10.1016/S0021-9258(18)56740-5

7. Uutela, P.; Reinilä, R.; Piepponen, P.; Ketola, R. A.; Kostiainen, R. Analysis of acetylcholine and choline in microdialysis samples by liquid chromatography/tandem mass spectrometry. Rapid Commun. Mass Spectrom. 2005, 19 (20), 2950-2956. https://doi.org/10.1002/rcm.2160.

8. Lin, S.; Liu, C.-C.; Chou, T.-C. Amperometric acetylcholine sensor catalyzed by nickel anode electrode. Biosens. Bioelectron. 2004,20 (1), 9-14. https://doi.org/10.1016/j.bios.2004.01.018.

9. Alfonta, L.; Katz, E.; Willner, I. Sensing of Acetylcholine by a Tricomponent-Enzyme Layered Electrode Using Faradaic Impedance Spectroscopy, Cyclic Voltammetry, and Microgravimetric Quartz Crystal Microbalance Transduction Methods. Anal. Chem. 2000, 72 (5), 927-935. https://doi. org/10.1021/ac990439d.

10. Kharitonov, A. B.; Zayats, M.; Lichtenstein, A.; Katz, E.; Willner, I. Enzyme monolayer-functionalized field-effect transistors for biosensor applications. Sensors and Actuators B: Chemical 2000, 70 (1), 222-231. https://doi.org/10.1016/S0925-4005(00)00573-6.

11. Chen, Z.; Ren, X.; Meng, X.; Chen, D.; Yan, C.; Ren, J.; Yuan, Y.; Tang, F. Optical detection of choline and acetylcholine based on $\mathrm{H}_{2} \mathrm{O}_{2}$-sensitive quantum dots. Biosens. Bioelectron. 2011, 28 (1), 50-55. https://doi.org/10.1016/j.bios.2011.06.041.

12. Ternaux, J.-P.; Chamoin, M.-C. Enhanced chemiluminescent assays for acetylcholine. J. Biolumin. Chemilumin. 1994, 9 (2), 65-72. https://doi. org/10.1002/bio.1170090205.

13. Fan, W.; Zhang, Z. Determination of Acetylcholine and Choline in Rat Brain Tissue by FIA with Immobilized Enzymes and Chemiluminescence Detection. Microchem. J. 1996, 53 (3), 290-295. https://doi.org/10.1006/mchj.1996.0043.

14. Sen, S.; Gülce, A.; Gülce, H. Polyvinylferrocenium modified Pt electrode for the design of amperometric choline and acetylcholine enzyme electrodes. Biosens. Bioelectron. 2004, 19 (10), 1261-1268. https://doi.org/10.1016/j.bios.2003.11.011.

15. Guerrieri, A.; Lattanzio, V.; Palmisano, F.; Zambonin, P. G. Electrosynthesized poly(pyrrole)/poly(2-naphthol) bilayer membrane as an effective anti-interference layer for simultaneous determination of acethylcholine and choline by a dual electrode amperometric biosensor. Biosens. Bioelectron. 2006, 21 (9), 1710-1718. https://doi.org/10.1016/j.bios.2005.08.005.

16. Carballo, R.; Dall'Orto, V. C.; Rezzano, I. Poly[Ni(II)Protoporphyrin IX] Modified Electrode for Amperometric Detection of Acetylcholine (Ach) and Choline (Ch). Anal. Lett. 2007, 40 (10), 1962-1971. https://doi.org/10.1080/00032710701484343. 
17. Keski-Rahkonen, P.; Lehtonen, M.; Ihalainen, J.; Sarajärvi, T.; Auriola, S. Quantitative determination of acetylcholine in microdialysis samples using liquid chromatography/atmospheric pressure spray ionization mass spectrometry. Rapid Commun. Mass Spectrom. 2007, 21 (18), $2933-2943$. https://doi.org/10.1002/rcm.3162.

18. Prokai, L.; Fryčák, P.; Stevens, S. M.; Nguyen, V. Measurement of Acetylcholine in Rat Brain Microdialysates by LC-Isotope Dilution Tandem MS. Chromatographia 2008, 68 (1), 101-105. https://doi.org/10.1365/s10337-008-0697-0.

19. Zhang, M.-Y.; Hughes, Z. A.; Kerns, E. H.; Lin, Q.; Beyer, C. E. Development of a liquid chromatography/tandem mass spectrometry method for the quantitation of acetylcholine and related neurotransmitters in brain microdialysis samples. J. Pharm. Biomed. Anal. 2007,44 (2), $586-593$. https://doi.org/10.1016/j.jpba.2007.02.024.

20. Schebb, N. H.; Fischer, D.; Hein, E.-M.; Hayen, H.; Krieglstein, J.; Klumpp, S.; Karst, U. Fast sample preparation and liquid chromatography-tandem mass spectrometry method for assaying cell lysate acetylcholine. J. Chromatogr. A 2008, 1183 (1), 100-107. https://doi.org/10.1016/j. chroma.2008.01.033.

21. Kunec-Vajić, E.; Weber, K. Acetylcholine as an activator of oxidation reactions. Experientia 1967, 23 (6), 432-433. https://doi.org/10.1007/ BF02142159.

22. Kunec-Vajić, E. The activating action of acetylcholine and pilocarpine on the oxidation of luminol. Experientia 1973, 29 (8), 1010-1012. https:// doi.org/10.1007/BF01930434.

23. Morel, N.; Israel, M. Applications to the Study of Acetylcholine Release of the Choline Oxidase Acetylcholine Assay. In Neurocytochemical Methods, Calas, A.; Eugène, D., Eds. Springer Berlin Heidelberg: Berlin, Heidelberg, 1991; pp 169-182.

Received: 31.01.2021

Revised: 20.02.2021

Accepted: 23.02.2021 